\title{
CHARACTERIZATION OF SULFIDED SPECIES USING TEMPERATURE-PROGRAMMED REDUCTION OF SULFIDED MOLYBDENUM CATALYSTS
}

\section{SATOSHI MATSUDA, KAZUHIRO INAMURA, YOSHIO AKAI and TOSHIYUKI TAKYU}

Central Research Laboratories, Idemitsu Kosan Co., Ltd.

Sodegaura, Chiba 299-02, Japan

\begin{abstract}
Temperature-programmed reduction of sulfided catalyst(TPR-S) was conducted for characterization of sulfided species produced by sulfurization. This method can provide quantitative information by monitoring $\mathrm{H}_{2}$ consumption and $\mathrm{H}_{2} \mathrm{~S}$ production due to different kinds of sulfided species. In this study, the sulfided species in $\mathrm{Mo} / \mathrm{Al}_{2} \mathrm{O}_{3}$ catalyst were characterized using this method. These results indicated the presence of adsorbed $\mathrm{H}_{2} \mathrm{~S}$ species on $\mathrm{Al}_{2} \mathrm{O}_{3}$ and sulfur- $\mathrm{Al}_{2} \mathrm{O}_{3}$ interaction species.
\end{abstract}

Key words TPR-S, Molybdenum, Sulfurization

\section{INTRODUCTION}

Hydrodesulfurization(HDS) catalysts such as $\mathrm{Co}-\mathrm{Mo} / \mathrm{Al}_{2} \mathrm{O}_{3}$ are usually sulfided before HDS reaction. Sulfurization as an activation process significantly influences on the sulfided states of catalysts and their HDS activities. TPR-S method proposed by Moulijn and co-workers[1] is one of useful techniques for characterization of sulfided species. TPR-S patterns for sulfided catalysts usually show several peaks which are attributed to different types of sulfided species.

TPR-S has the following advantages.

-Ultraviolet-spectrometer(UV, set at $202 \mathrm{~nm}$ ) is used for the detection of $\mathrm{H}_{2} \mathrm{~S}$. In comparison with gas chromatography, UV is more sensitive and convenient for monitoring $\mathrm{H}_{2} \mathrm{~S}$ on-line system.

$-\mathrm{H}_{2}$ consumption and $\mathrm{H}_{2} \mathrm{~S}$ production can be quantitatively monitored.

-All sulfided species can be reduced at high temperature up to $1350 \mathrm{~K}$.

- In situ measurement of sulfided catalyst is possible.

In this study, a similar instrument as reported one[1] was used for the characterization of sulfided species in the sulfided $\mathrm{Mo} / \mathrm{Al}_{2} \mathrm{O}_{3}$ catalyst.

\section{EXPERIMENTAL}

Materials $\mathrm{MoS}_{2}$ powder(Wako Pure Chemical) and $\mathrm{Al}_{2} \mathrm{O}_{3}$ support(Surface area, $190 \mathrm{~m}^{2} / \mathrm{g}$; Amount of impurity $\left(\mathrm{SO}_{4}{ }^{2-}\right)$ is 0.01 as $\mathrm{S} / \mathrm{Al}_{2} \mathrm{O}_{3}$ molar ratio) were used as references. $\mathrm{Mo} / \mathrm{Al}_{2} \mathrm{O}_{3}$ catalyst $\left(10 \mathrm{wt} \%\right.$ as $\left.\mathrm{MoO}_{3}\right)$ was prepared by vacuum impregnation of $\mathrm{Al}_{2} \mathrm{O}_{3}$ support with a $\left(\mathrm{NH}_{4}\right)_{6} \mathrm{Mo}_{7} \mathrm{O}_{24}$ solution.

TPR-S The catalyst was packed in a quartz reactor in an oven. $\mathrm{Mo} / \mathrm{Al}_{2} \mathrm{O}_{3}$ catalyst was calcined at $650 \mathrm{~K}$ for $2 \mathrm{hr}$, and then cooled to room temperature. This was exposed to the sulfiding gas $\left(3 \% \mathrm{H}_{2} \mathrm{~S}, 23 \% \mathrm{H}_{2}, 74 \% \mathrm{Ar}\right)$ at room temperature for $2 \mathrm{hr}$. The catalyst was sulfided with a sulfiding gas flow at a constant heating rate of $10 \mathrm{~K} / \mathrm{min}$ from $300 \mathrm{~K}$ to $650 \mathrm{~K}$, and kept at $650 \mathrm{~K}$ for $30 \mathrm{~min}$. Sulfiding gas was purged by Ar gas after the sample was cooled to room temperature. After replacement by the reducing gas $\left(65 \% \mathrm{H}_{2}, 35 \% \mathrm{Ar}\right)$, the catalyst was reduced at a constant heating rate of $10 \mathrm{~K} / \mathrm{min}$ from $300 \mathrm{~K}$ to $1350 \mathrm{~K}$, and kept at $1350 \mathrm{~K}$ for $30 \mathrm{~min}$. On reduction of the sulfided catalyst(TPR-S measurement), $\mathrm{H}_{2} \mathrm{~S}$ was monitored by UV detector. Sequentially, $\mathrm{H}_{2}$ through a trap of molecular sieves for $\mathrm{H}_{2} \mathrm{O}$ and $\mathrm{H}_{2} \mathrm{~S}$ was detected by thermal conductivity detector(TCD). 


\section{RESULTS AND DISCUSSION}

$\mathrm{MOS}_{2}$ Fig. 1 shows TPR-S patterns of $\mathrm{MoS}_{2}$ powder. Peaks of $\mathrm{H}_{2}$ consumption and $\mathrm{H}_{2} \mathrm{~S}$ production can be observed at more than ca. $1000 \mathrm{~K}$. Intensities of these peaks increase with increasing reduction temperature up to $1350 \mathrm{~K}$. Reduction of Mo species continues in the isothermal range and then decreases gradually. Molar ratios of $\mathrm{H}_{2}$ consumption and $\mathrm{H}_{2} \mathrm{~S}$ production to Mo are of $2.12 \pm 0.06$ and of $1.94 \pm 0.06$, respectively. These values are in good agreement with the estimated value of 2.0 by assuming reduction of $\mathrm{MoS}_{2}$ to $\mathrm{Mo}$ metal. This result indicates that reduction of $\mathrm{MoS}_{2}$ can be quantitatively analyzed by TPR-S measurement. $\underline{\mathrm{Al}}_{2} \underline{\mathrm{O}}_{3}$ support Fig. 2 shows TPR-S patterns of $\mathrm{Al}_{2} \mathrm{O}_{3}$

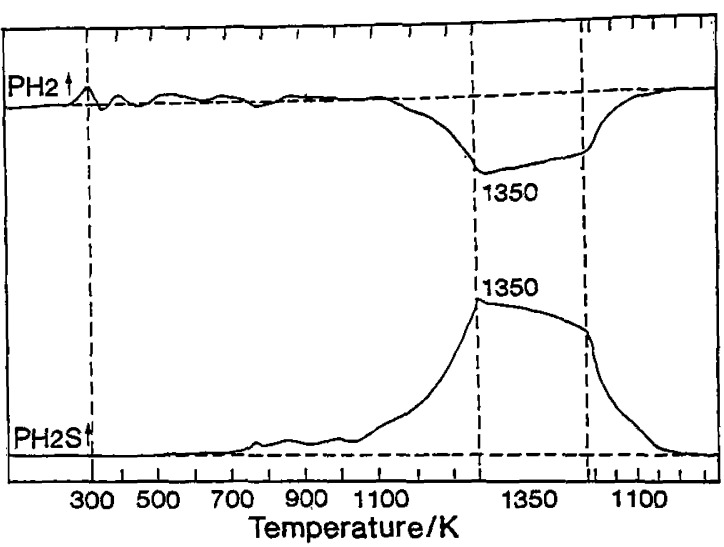

Fig.1 TPR-S patterns of $\mathrm{MoS}_{2}$ powder. support. Patterns for $\mathrm{H}_{2} \mathrm{~S}$ show four peaks centered at $387,489,729$, and $939 \mathrm{~K}$. $\mathrm{H}_{2} \mathrm{~S}$ production peaks at 387 and $489 \mathrm{~K}$ are not accompanied with $\mathrm{H}_{2}$ consumption peaks. The amount of $\mathrm{H}_{2} \mathrm{~S}$ adsorbed on $\mathrm{Al}_{2} \mathrm{O}_{3}$ support is 0.02 as $\mathrm{S} / \mathrm{Al}_{2} \mathrm{O}_{3}$ molar ratio. Okamoto et al. reported that $\mathrm{H}_{2} \mathrm{~S}$ desorption on $\mathrm{Al}_{2} \mathrm{O}_{3}$ occurred at 400 and $560 \mathrm{~K}$ in their temperature-programmed desorption study[2]. Therefore, the peaks at 387 and $489 \mathrm{~K}$ are also attributed to adsorbed $\mathrm{H}_{2} \mathrm{~S}$ on $\mathrm{Al}_{2} \mathrm{O}_{3}$ support.

Broad peaks of $\mathrm{H}_{2} \mathrm{~S}$ production and $\mathrm{H}_{2}$ consumption are observed at $729 \mathrm{~K}$. Molar ratio of sulfur estimated from $\mathrm{H}_{2} \mathrm{~S}$ production $\left(\mathrm{S} / \mathrm{Al}_{2} \mathrm{O}_{3}=0.01\right.$ ) is similar to that of sulfur impurity in $\mathrm{Al}_{2} \mathrm{O}_{3}$ support. However, peaks for hydrogeneration of sulfur impurity are apparently observed at $939 \mathrm{~K}$. Furthermore, $\mathrm{H}_{2} \mathrm{~S} / \mathrm{H}_{2}$ ratio 1.1 indicates that $\mathrm{H}_{2}$ is consumed for hydrogeneration of sulfur. Thus, these results suggest that sulfur- $\mathrm{Al}_{2} \mathrm{O}_{3}$ interaction species are formed on sulfurization.

$\underline{\mathrm{Mo} / \mathrm{Al}_{2}} \mathrm{O}_{3}$ catalyst TPR-S patterns of $\mathrm{Mo} / \mathrm{Al}_{2} \mathrm{O}_{3}$ catalyst are shown in Fig.3. Patterns of $\mathrm{H}_{2}$ consumption and $\mathrm{H}_{2} \mathrm{~S}$ production show four peaks centered at $465,729,909$, and $1350 \mathrm{~K}$. Three sets of these peaks are attributed to the following sulfided species, as reported previously[1];

Peaks at 465K: Chemisorbed sulfur produced from $\mathrm{H}_{2} \mathrm{~S}$ decomposition on Mo-sulfided species.

Peaks at 909K: Mo-oxysulfided species.

Peaks at 1350K: $\mathrm{MoS}_{2}$-like species.

Peaks at $729 \mathrm{~K}$ are similar to those of $\mathrm{Al}_{2} \mathrm{O}_{3}$ support. The result indicates sulfur- $\mathrm{Al}_{2} \mathrm{O}_{3}$ interaction species are also formed in sulfided $\mathrm{Mo} / \mathrm{Al}_{2} \mathrm{O}_{3}$ catalyst. However, $\mathrm{H}_{2} \mathrm{~S}$ desorption peaks are not clearly observed in $\mathrm{H}_{2} \mathrm{~S}$ patterns of sulfided $\mathrm{Mo} / \mathrm{Al}_{2} \mathrm{O}_{3}$ catalyst. A decrease in $\mathrm{H}_{2} \mathrm{~S}$ adsorption might be due to a decrease in $\mathrm{Al}_{2} \mathrm{O}_{3}$ surface caused by Mo loading. Furthermore, no peaks for hydrogeneration of sulfur impurity are observed. State of sulfur impurity in $\mathrm{Mo} / \mathrm{Al}_{2} \mathrm{O}_{3}$ catalyst may be different from that in $\mathrm{Al}_{2} \mathrm{O}_{3}$ support.

Molar ratios of $\mathrm{H}_{2} \mathrm{~S}$ production and $\mathrm{H}_{2}$ consumption to Mo are 2.20 and 2.81, respectivity. These values are larger than the stoichiometric ratio of 2.0 for $\mathrm{MoS}_{2}$. The presence of excess sulfur indicates the existence of adsorbed $\mathrm{H}_{2} \mathrm{~S}$, chemisorbed sulfur, and sulfur- $\mathrm{Al}_{2} \mathrm{O}_{3}$ interaction species.

In conclusion, two sulfided species such as $\mathrm{H}_{2} \mathrm{~S}$ adsorbtion onto $\mathrm{Al}_{2} \mathrm{O}_{3}$ support and sulfur- $\mathrm{Al}_{2} \mathrm{O}_{3}$ interaction species were also observed in TPR-S measurement of $\mathrm{Mo} / \mathrm{Al}_{2} \mathrm{O}_{3}$ catalyst, in addition to sulfided species reported previously[1].

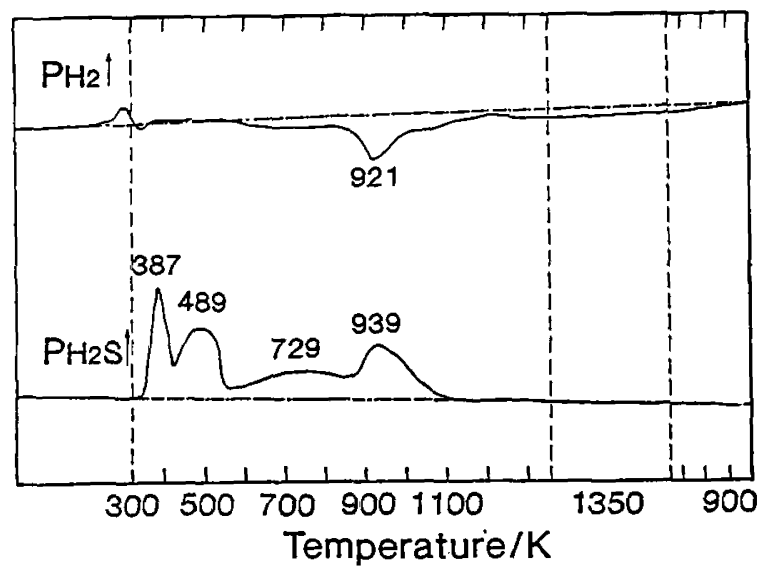

Fig.2 TPR-S patterns of $\mathrm{Al}_{2} \mathrm{O}_{3}$ support.

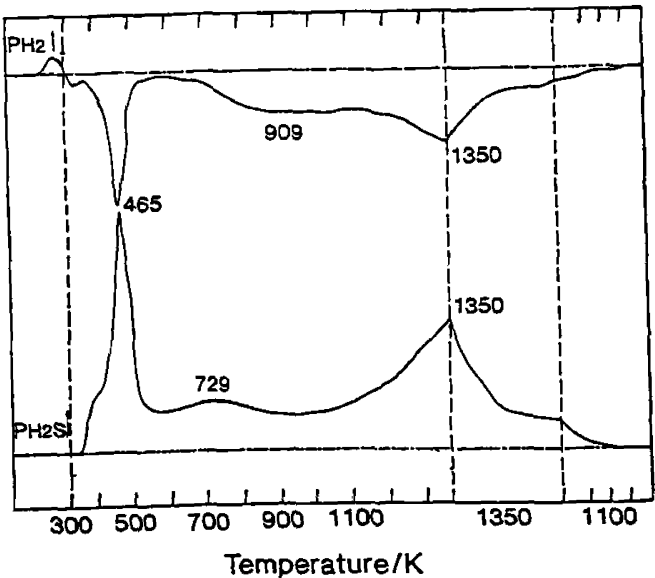

Fig. 3 TPR-S patterns of $\mathrm{Mo} / \mathrm{Al}_{2} \mathrm{O}_{3}$ catalyst.

\section{REFERENCES}

1. B.Scheffer, N.J.J.Dekker, P.J.Magnus, and J.A.Moulijn, J.Catal., 121, 31(1990),

2. Y.Okamoto, M.Oh-hara, A.Maezawa, T.Imanaka, and S.Teranishi, J.Phys.Chem., 90, 2396(1986). 